\title{
E-Commerce Performance with Cloud Computing
}

\author{
D.Jeyapriya S.Theivasigamani, R.Velvizhi, P.Nandhini
}

\begin{abstract}
Electronic Commerce or E-Commerce is a term for a business that incorporates the trading of information over the web. It covers an extent of different kind of business from buyer based retail goals, trough closeout or music site, to business exchanges trading items and ventures between undertakings. The web of things is the arrangement of a physical inquiry embedded with devices, programming, sensors and framework accessibility that engages to assemble and exchange data. This paper will illuminate how IOT is executed in online business experience nearby the delineation of Amazon dash an IOT advancement made by Amazon
\end{abstract}

Index Terms: IOT(Internet of Thing); E-Commerce;Sensor;

\section{INTRODUCTION}

Web of thing is an Integrated piece of future web and could be characterized as worldwide system framework with [2 ], [ 4],[6]self-designing capacities in light of standard interoperable correspondence convention where physical and virtual thing have personality physical trait and utilize astute interfaces, essentially the web of thing is an arrangement of interrelated processing gadget ,machine or individuals that are furnished with one of a kind identifiers and capacity to exchange information over system without expecting human to human communication. [1],[3],[5]

\section{ONLINE BUSINESS}

Online business or Electronic Commerce is exchanging of good utilizing internet,e-trade is directed utilizing an assortment of uses, for example, email, fax EDI (Electronic Data Interchange) File Transfer Protocol. The principal web based business created was in the year 1972 where ARPANET was utilized to cannabis deal between the understudy of Artificial Intelligence research facility and Massachusetts Institute of Technology Some of the normal application identified with web based business are as per the following. [8],[ 10] ,[12]

\section{A. Archive Automation}

Revised Manuscript Received on July 22, 2019.

D.Jayapriya , Department of CSE ,Bharath Institute of Higher Education and Reaesrch,Chennai,Thamilnadu,India.

S.Theivasigamani ,Deparrtment of CSE, Bharath Institute of Higher Education and Research Chenai,Thamilnadu ,India.

R.Velvizhi , Department of CSE ,Bharath Institute of Higher Education and Reaesrch,Chennai,Thamilnadu,India.

P.Nandhini ,Deparrtment of CSE, Bharath Institute of Higher Education and Research Chenai,Thamilnadu ,India.
It is the path toward sketching out of structure and work forms that help with the arrangement of electronic records. Motorization system urges associations to confine data segment, diminish the time spent in altering and moreover the danger related in light of human screw up. The essential limit is to supplant manual chronicle of files with arrange based system where customer answer data area screen. Some file automation writing computer programs are even prepared for making a lone record suite where all the indispensable report is exemplified into one single archive so invigorating ought to be conceivable easily. There are numerous files that are utilized as a part of the business which includes solicitations/bundling list/slips and so forth. These archives are normally contracts amongst collector and sender and are essential to both the gatherings and additionally the administration. Archives taking care of in production network administration is normally performed by Barcode scanner and laser printer. There are a few organizations of a fast record robotization framework that contrast the laser printed report with arrange an embed a pocket to the delivery compartment .

[7],[ 9], [11]

\section{B. Gathering Buying}

Gathering Buying is where items are given at lessened cost just if a base number of purchasers would influence the buy .To aggregate purchasing is additionally used to buy land in India a site called assemble booking give a different [14],[ 16], [18] arrangement on land booking. As of now there are more than 40 enrolled destinations working in India. [13], [15], [ 17]

\section{Print on Demand}

It is fundamentally a printing innovation and a business procedure in which duplicates of books are not printed until the point when a request has been gotten. Print on request is utilized as a method for printing things for a settled cost for each duplicate. Case has a few advantages which incorporate lower cost; specialized setup is snappy and practically zero waste from the unsold item[19],[21],[23]

\section{Web based Banking}

Web based saving money is an electronic installment framework that empowers clients of a bank to check status of their record, pay charges, exchange money ask for check book and so forth without going to bank every one of the administrations are made do with help of PCs and the web as a result of diminished overhead cost related with not having physical branches, online bank tend to offer purchasers a huge sparing and pay high-loan fees. 
The online bank handles client undertaking by email, telephone or online talk. There are a few issues related with web of thing which are as per the following: [20],[22], [24] I. Security-IOT security comprises of defending of associated gadgets and systems in the web of things

The results of IOT are frequently comprises of old implanted working framework and programming which can be effortlessly bargained by the interloper to enhance the security an IOT device ought to be clearly accessible over the web, ought to be fragmented into its own particular system and have arrange get to confined .In 2013 an examination at Proofpoint found the principal IOT botnet which is a gathering of hacked computers,smart apparatuses, and IOT gadgets that have been co-decided on illegal purposes. [25],[27],[29]

II. Security IOT security is the uncommon contemplations which is required to shield the data of client from presentation in IOT condition in which any physical or sensible element or protest might be relegated a novel identifier and capacity to impart self-rulingly finished internet,as clients day by day conduct and movement are measures,recorded and broke down there is strict requirement for designers and strategy creators to guarantee that what sort of data will be gathered and to what extent it will be put away or dissected . [26],[28],[30]

III.Venture There are a few difficulties for the endeavor to overcome for as to utilize IOT all the more productively one of them being interruption a disavowal of administration assault, a foreswearing of administration assault is where organize asset is inaccessible to the client by suspending administrations of a host associated with the internet.This circumstance can bring about influencing a cheerful client to go disappointed bringing about an income misfortune for the undertaking. [31],[33],[35]

IV. Capacity Management-Organizations utilize IOT gadgets to improve business and enhance client satisfaction,but after information has been exchanged it needs to assemble in a limit structure which is influencing associations to rethink their information stockpiling framework system,cloud capacity framework has a few favorable position one of being an immediate association amongst gadget and open cloud supplier which implies information can be put away quicker bringing about less stockpiling on gadget and lower gadget cost V. Server-The effect of IoT on the server market will be to a great extent concentrated on expanded interest in key vertical organizations and affiliations related to those business undertakings where IoT can be productive, or include now to process both short strings and huge recordsmilar Join calculation for strings comparative join depends on [32],[34],[36]

Guide Reduce which is executed by consolidating blend calculation and utilized the light weight channels for character based comparable capacities and set comparable capacities. By utilizing consolidate calculation, the quantity of significant worth key sets are diminished to substantial number degree, without decreasing the trimmingpower.
Light weight channel units decreases the quantity of competitor sets, which will builds the execution and diminishes the transmission cost. The Similar join calculation is capable now to process both short strings and huge records noteworthy value.moreover, an enormous exhibit of the gadget will require a substantial limit server and a high spending plan. [37],[39],[41]

VI. Server farm Network-Existing server farm WAN connections have been worked for direct data transmission prerequisites made by our present utilization of innovation. However,as the amount of information being moved is characterize to build the requirement for extended bandwidth.Data reinforcement can be troublesome as a result of both system transmission capacity .This implies organizations should bolster specifically, robotizing the way toward choosing which information are important or important to keep. The robotization of this procedure can be another huge information hindrance of its own. IOT is a quickly developing administration till 2020 there would be more than 38 Billion unit of associated gadgets yet there are some issue with respect to IOT that should be settled in the first place, amazon dash is only one major advance toward future enhancing its component and application region can build efficiency besides giving an open beta method of dash could be useful in giving more precise outcome and input from users.Internet of thing is improving an establishment for a keen city to useful online business .Periodicresearch and up degree can help it to develop on a considerably bigger scale. The advancement of the cutting edge portable framework will rely upon the imagination of the clients in planning new applications. IoT is a perfect developing innovation to impact this space by giving new advancing information and the required computational assets for making progressive apps. The different usage and capacities of IOT can clearly legitimize the announcement that IOT is the "Fate Of Things[38],[40]

\section{REFERENCES}

[1] Kumarave A., Rangarajan K.,Algorithm for automaton specification for exploring dynamic labyrinths,Indian Journal of Science and Technology,V-6,I-SUPPL5,PP-4554-4559,Y-2013

[2] P. Kavitha, S. Prabakaran "A Novel Hybrid Segmentation Method with Particle Swarm Optimization and Fuzzy C-Mean Based On Partitioning the Image for Detecting Lung Cancer" International Journal of Engineering and Advanced Technology (IJEAT) ISSN: 2249-8958, Volume-8 Issue-5, June 2019

[3] Kumaravel A., Meetei O.N.,An application of non-uniform cellular automata for efficient cryptography,2013 IEEE Conference on Information and Communication Technologies, ICT 2013,V-,I-,PP-1200-1205,Y-2013

[4] Kumarave A., Rangarajan K.,Routing alogrithm over semi-regular tessellations,2013 IEEE Conference on Information and Communication Technologies, 2013,V-,I-,PP-1180-1184,Y-2013

[5] P. Kavitha, S. Prabakaran "Designing a Feature Vector for Statistical Texture Analysis of Brain Tumor" International Journal of Engineering and Advanced Technology (IJEAT) ISSN: 2249-8958, Volume-8 Issue-5, June 2019

[6] Dutta P., Kumaravel A.,A novel approach to trust based identification of leaders in social networks,Indian Journal of Science and Technology,V-9,I-10,PP--,Y-2016

[7] Kumaravel A., Dutta P.,Application of Pca for context selection for collaborative filtering,Middle - East Journal of Scientific Research,V-20,I-1,PP-88-93,Y-2014

[8] Kumaravel A., Rangarajan K.,Constructing an automaton for exploring 
dynamic labyrinths,2012 International Conference on Radar, Communication and Computing, ICRCC 2012,V-,I-,PP-161-165,Y-2012

[9] P. Kavitha, S. Prabakaran "Adaptive Bilateral Filter for Multi-Resolution in Brain Tumor Recognition" International Journal of Innovative Technology and Exploring Engineering (IJITEE) ISSN: 2278-3075, Volume-8 Issue-8 June, 2019

[10] Kumaravel A.,Comparison of two multi-classification approaches for detecting network attacks,World Applied Sciences Journal,V-27,I-11,PP-1461-1465,Y-2013

[11] Tariq J., Kumaravel A.,Construction of cellular automata over hexagonal and triangular tessellations for path planning of multi-robots,2016 IEEE International Conference on Computational Intelligence and Computing Research, ICCIC 2016,V-,I-,PP--,Y-2017

[12] Sudha M., Kumaravel A.,Analysis and measurement of wave guides using poisson method,Indonesian Journal of Electrical Engineering and Computer Science,V-8,I-2,PP-546-548,Y-2017

[13] Ayyappan G., Nalini C., Kumaravel A.,Various approaches of knowledge transfer in academic social network,International Journal of Engineering and Technology,V-,I-,PP-2791-2794,Y-2017

[14] Kaliyamurthie, K.P., Sivaraman, K., Ramesh, S. Imposing patient data privacy in wireless medical sensor networks through homomorphic cryptosystems 2016, Journal of Chemical and Pharmaceutical Sciences 92.

[15] Kaliyamurthie, K.P., Balasubramanian, P.C. An approach to multi secure to historical malformed documents using integer ripple transfiguration 2016 Journal of Chemical and Pharmaceutical Sciences 92

[16] A.Sangeetha,C.Nalini,"Semantic Ranking based on keywords extractions in the web", International Journal of Engineering \& Technology, 7 (2.6) (2018) 290-292

[17] S.V.GayathiriDevi,C.Nalini,N.Kumar,"An efficient software verification using multi-layered software verification tool "International Journal of Engineering \& Technology, 7(2.21)2018 454-457

[18] C.Nalini,ShwtambariKharabe,"A Comparative Study On Different Techniques Used For Finger - Vein Authentication”, International Journal Of Pure And Applied Mathematics, Volume 116 No. 8 2017, 327-333, Issn: 1314-3395

[19] M.S. Vivekanandan and Dr. C. Rajabhushanam, "Enabling Privacy Protection and Content Assurance in Geo-Social Networks", International Journal of Innovative Research in Management, Engineering and Technology, Vol 3, Issue 4, pp. 49-55, April 2018.

[20] Dr. C. Rajabhushanam, V. Karthik, and G. Vivek, "Elasticity in Cloud Computing", International Journal of Innovative Research in Management, Engineering and Technology, Vol 3, Issue 4, pp. 104-111, April 2018.

[21] K. Rangaswamy and Dr. C. Rajabhushanamc, "CCN-Based Congestion Control Mechanism In Dynamic Networks", International Journal of Innovative Research in Management, Engineering and Technology, Vol 3, Issue 4, pp. 117-119, Apri 2018

[22] Kavitha, R., Nedunchelian, R., "Domain-specific Search engine optimization using healthcare ontology and a neural network backpropagation approach", 2017, Research Journal of Biotechnology, Special Issue 2:157-166

[23] Kavitha, G., Kavitha, R., "An analysis to improve throughput of high-power hubs in mobile ad hoc network" , 2016, Journal of Chemical and Pharmaceutical Sciences, Vol-9, Issue-2: 361-363

[24] Kavitha, G., Kavitha, R., "Dipping interference to supplement throughput in MANET" , 2016, Journal of Chemical and Pharmaceutical Sciences, Vol-9, Issue-2: 357-360

[25] Michael, G., Chandrasekar, A.,"Leader election based malicious detection and response system in MANET using mechanism design approach", Journal of Chemical and Pharmaceutical Sciences(JCPS) Volume 9 Issue 2, April - June 2016

[26] Michael, G., Chandrasekar, A.,"Modeling of detection of camouflaging worm using epidemic dynamic model and power spectral density", Journal of Chemical and Pharmaceutical Sciences(JCPS) Volume 9 Issue 2, April - June 2016

[27] Pothumani, S., Sriram, M., Sridhar, J., Arul Selvan, G., Secure mobile agents communication on intranet,Journal of Chemical and Pharmaceutical Sciences, volume 9, Issue 3, Pg No S32-S35, 2016

[28] Pothumani, S., Sriram, M., Sridhar, Various schemes for database encryption-a survey, Journal of Chemical and Pharmaceutical Sciences, volume 9, Issue 3, Pg NoS103-S106, 2016

[29] Pothumani, S., Sriram, M., Sridhar, A novel economic framework for cloud and grid computing, Journal of Chemical and Pharmaceutical Sciences, volume 9, Issue 3, Pg No S29-S31, 2016
[30] Priya, N., Sridhar, J., Sriram, M. "Ecommerce Transaction Security Challenges and Prevention Methods- New Approach" 2016 Journal of Chemical and Pharmaceutical Sciences, JCPS Volume 9 Issue 3.page no:S66-S68

[31] Priya, N.,Sridhar,J.,Sriram, M."Vehicular cloud computing security issues and solutions" Journal of Chemical and Pharmaceutical Sciences(JCPS) Volume 9 Issue 2, April - June 2016

[32] Priya, N., Sridhar, J., Sriram, M. "Mobile large data storage security in cloud computing environment-a new approach" JCPS Volume 9 Issue 2. April - June 2016

[33] Anuradha.C, Khanna.V, "Improving network performance and security in WSN using decentralized hypothesis testing "Journal of Chemical and Pharmaceutical Sciences(JCPS) Volume 9 Issue 2, April - June 2016 .

[34] Anuradha.C, Khanna.V, "A novel gsm based control for e-devices" Journal of Chemical and Pharmaceutical Sciences(JCPS) Volume 9 Issue 2, April - June 2016 .

[35] Anuradha.C, Khanna.V, "Secured privacy preserving sharing and data integration in mobile web environments " Journal of Chemical and Pharmaceutical Sciences(JCPS) Volume 9 Issue 2, April - June 2016 .

[36] Sundarraj, B., Kaliyamurthie, K.P. Social network analysis for decisive the ultimate classification from the ensemble to boost accuracy rates 2016 International Journal of Pharmacy and Technology 8

[37] Sundarraj, B., Kaliyamurthie, K.P. A content-based spam filtering approach victimisation artificial neural networks 2016 International Journal of Pharmacy and Technology $\quad 8 \quad 3$

[38] Sundarraj, B., Kaliyamurthie, K.P. Remote sensing imaging for satellite image segmentation 2016 International Journal of Pharmacy and Technology 83 .

[39] Sivaraman, K., Senthil, M. Intuitive driver proxy control using artificial intelligence2016 International Journal of Pharmacy and Technology 84.

[40] Sivaraman, K., Kaliyamurthie, K.P. Cloud computing in mobile technology2016 Journal of Chemical and Pharmaceutical Sciences 92.

[41] Sivaraman, K., Khanna, V.Implementation of an extension for browser to detect vulnerable elements on web pages and avoid click jacking 2016 Journal of Chemical and Pharmaceutical Sciences 92.

\section{AUTHORS PROFILE}

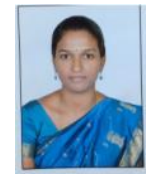

D.Jayapriya ， Department of CSE ,Bharath Institute of Higher Education and Reaesrch,Chennai,Thamilnadu,India.

S.Theivasigamani ,Deparrtment of CSE, Bharath Institute of Higher Education and Research Chenai,Thamilnadu ,India

R.Velvizhi ,Deparrtment of CSE, Bharath Institute of Higher Education and

Research Chenai,Thamilnadu ,India
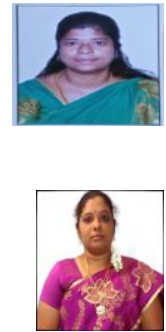

P.Nandhini ,Deparrtment of CSE, Bharath Institute of Higher Education and Research Chenai,Thamilnadu ,India 